\title{
Effect of Fertilizer Rate on Growth of Azalea and Holly in Pine Bark and Pine Tree Substrates
}

\author{
Brian E. Jackson ${ }^{1,5}$, Robert D. Wright ${ }^{2}$, Jake F. Browder ${ }^{3}$, \\ J. Roger Harris ${ }^{5}$, and Alex X. Niemiera ${ }^{4}$ \\ Department of Horticulture, Virginia Polytechnic Institute \& State \\ University, 301 Saunders Hall, Blacksburg, VA 24061
}

Additional index words. container substrate, fertilization, ground trees, loblolly pine, nutrition, peat alternative, Pinus taeda L., pine chips, potting media, wood substrate, WoodGro ${ }^{\mathrm{TM}}$

\begin{abstract}
Recent interest in the use of wood substrates in horticulture crop production has justified the need for determining fertilizer requirements in these substrates compared with traditional pine bark (PB) and peatmoss substrates. The objective was to determine the response of japanese holly (Ilex crenata Thunb. 'Compacta') and azalea (Rhododendron obtusum Planck. 'Delaware Valley') grown in a pine tree substrate (PTS) (trade name WoodGro $^{\mathrm{TM}}$ ) or milled $\mathrm{PB}$ to fertilizer rate. Pine tree substrate is produced from freshly harvested loblolly pine trees (Pinus taeda L.) that are delimbed, chipped, and ground in a hammer mill to a desired particle size. Japanese holly plants were grown in 2.8-L containers in the fall of 2005 and again in the spring of 2007 with the addition of azalea. Plants grown in PTS or PB were fertilized by incorporating Osmocote Plus fertilizer $(15 \mathrm{~N}-3.9 \mathrm{P}-10 \mathrm{~K})$ at rates of $3.5,5.9,8.3 \mathrm{or} 10.6 \mathrm{~kg} \cdot \mathrm{m}^{-3}$ for japanese holly and 1.2, $3.5,5.9$, or $8.3 \mathrm{~kg} \cdot \mathrm{m}^{-3}$ for azalea. After 3 months, shoot dry weights were determined for japanese holly and azalea. Japanese holly root dry weights were determined for both experiments, and substrate $\mathrm{CO}_{2}$ efflux $\left(\mu \mathrm{mol} \mathrm{CO}_{2} \mathrm{~m}^{-2} \cdot \mathrm{s}^{-1}\right)$ was measured on the treatments at the end of the experiment using a LI-6400 soil $\mathrm{CO}_{2}$ flux chamber. In 2005, japanese holly shoot dry weights of PTS-grown plants were comparable to plants grown in PB at the $8.3 \mathrm{~kg} \cdot \mathrm{m}^{-3}$ fertility rate, and shoot dry weights of PTS-grown plants were higher than $P B$ at the $10.6 \mathrm{~kg} \cdot \mathrm{m}^{-3}$ rate. In 2007, japanese holly and azalea shoot dry weights of PTSgrown plants were comparable to $P B$ plants at the $5.9 \mathrm{~kg} \cdot \mathrm{m}^{-3}$ fertilizer rate. Both japanese holly and azalea achieved shoot growth in PTS comparable to shoot growth in $\mathrm{PB}$ with $\approx 2.4 \mathrm{~kg} \cdot \mathrm{m}^{-3}$ additional fertilizer for $\mathrm{PTS}$. Substrate $\mathrm{CO}_{2}$ efflux rates were higher in PTS compared with PB indicating higher microbial activity, thereby increasing the potential for nutrient immobilization in PTS.
\end{abstract}

The nursery and greenhouse industries have experienced tremendous growth over the last four decades. Brooker et al. (2000) reported that the nursery and greenhouse industries have increased economically from $\$ 661$ million in 1960 to $\$ 12.11$ billion in 1998. The nursery industry has undergone many changes and innovations during this time to more efficiently and properly manage irrigation, fertility, substrate use, integrated pest management, and so on (Bilderback, 2001; Yeager et al., 2007). Of these, research and development of new substrates to replace conventionally used peatmoss and pine bark (PB) substrates have increased in recent years. In addition to developing and using

\footnotetext{
Received for publication 19 Feb. 2008. Accepted for publication 6 Apr. 2008.

The research reported herein was partially funded by the Virginia Agricultural Council, the Virginia Nursery and Landscape Association, and the West Virginia Nursery and Landscape Association.

${ }^{1}$ Graduate Teaching Assistant.

${ }^{2}$ Professor.

${ }^{3}$ Research Associate.

${ }^{4}$ Associate Professor.

${ }^{5}$ To whom reprint requests should be addressed; e-mail jacksonb@vt.edu
}

new substrates, much work has focused on managing fertility and irrigation programs of these substrates to maximize plant performance and minimize nutrient loss resulting from environmental concerns (Gouin and Link, 1973; Warren and Bilderback, 2004). The need to develop new substrates and fertility management programs for the horticulture industry is an issue that is being addressed by researchers around the world.

Research in Europe has been conducted for over two decades on the development of alternative and renewable horticultural substrates composed of wood. The need for alternative substrates is in response to decreased peat use resulting from environmental regulations on the mining of peat bogs (Carlile, 2004; Riviere and Caron, 2001). Researchers have had success using wood substrates and have developed several commercialized products currently available to growers (Gumy, 2001; Penningsfeld, 1992).

Serious consideration is also being given to the development of alternative, organic container substrates here in the United States based on recent substrate shortages and increased substrate costs (Griffith, 2007; Lu et al., 2006). Ground melaleuca trees (Melaleuca quinquenervia Cav.) were shown to be an acceptable substitute for bark or sedge peat when used to grow a number of woody and herbaceous plants (Conover and Poole, 1983; Ingram and Johnson, 1983). No phytotoxicity problems were evident in these studies as long as the proportion of melaleuca did not exceed $50 \%$ of the substrate volume. Kenna and Whitcomb (1985) demonstrated that Pyracantha $\times$ 'Mojave' and Liquidambar formosana Hance. grew as well in a substrate of woodchips:peat:sand $(3: 1: 1 \mathrm{v} / \mathrm{v} / \mathrm{v})$ as in a substrate composed of bark:peat: sand $(3: 1: 1 \mathrm{v} / \mathrm{v} / \mathrm{v})$. Wood chips for their study were produced by grinding entire trees, including leaves, twigs, bark, and wood of post oak (Quercus stellata Wangh.) and Siberian elm (Ulmus pumila L.). Noncomposted sawdust from Douglas fir (Pseudotsuga menziesii Mirb.) and western hemlock (Tsuga heterophylla Raf.) have also been used to grow a wide range of herbaceous and woody container crops in Canada where sawdust is plentiful (Maas and Adamson, 1972).

Laiche and Nash (1986) produced a pine tree substrate (PTS) derived from PB with a considerable percentage of pine wood and a second PTS derived from whole pine trees (needles, twigs, bark, and wood). They reported that plant growth (Rhododendron indica L. 'President Clay', Ligustrum sinense Lour. 'Variegata', and Ilex crenata Thunb. 'Compacta') was highest in $100 \%$ PB compared with the two PTSs and that additional work was needed before pine wood could be used as a container substrate. Two decades later, Wright and Browder (2005) demonstrated that japanese holly (Ilex crenata Thunb. 'Chesapeake'), azalea (Rhododendron obtusum Planck. 'Karen'), and marigold (Tagetes erecta Big. 'Inca Gold') could be grown in a noncomposted PTS $(100 \%$ wood $)$ produced from debarked loblolly pine trees. Nutrient analysis of the PTS substrate solution indicated that nutrient levels and $\mathrm{pH}$ were acceptable for plant culture, although extra fertilizer was added to PTS to maintain comparable electrical conductivity (EC) levels between the two substrates. Wright et al. (2006) also evaluated the growth of numerous woody nursery species in a PTS produced from ground pine logs (including the bark) $(\approx 90 \%$ wood and $10 \%$ bark) compared with PB. Results from this work concluded that plant dry weights were generally higher in $\mathrm{PB}$ than PTS, but differences in growth between PB and PTS were less when plants were supplied with higher fertilizer rates $(21 \mathrm{~g}$ versus 15 g Osmocote Plus $15 \mathrm{~N}-3.9 \mathrm{P}-10 \mathrm{~K}$; O.M. Scott Horticulture Products, Maryville, $\mathrm{OH})$. Growth differences in these studies were attributed to lower nutrient levels in the PTS resulting from either leaching or microbial immobilization of applied nutrients.

Fain et al. (2008) manufactured a PTS (referred to as WholeTree) by chipping and grinding freshly harvested 8- to 10-year-old pine trees including the wood, bark, limbs, and needles. They reported that vinca (Catharanthus roseus L.) grown in PTS were 
smaller than plants grown in $100 \% \mathrm{~PB}$, but that growth index and visual quality of the plants were similar for both substrates. Further work by Boyer et al. (2006) showed that growth of ageratum (Ageratum houstonianum Mill. 'Blue Hawaii') and salvia (Salvia ×superba Stapf. 'Vista Purple') was comparable to $100 \% \mathrm{~PB}$ when grown in a substrate derived from a tree byproduct (limbs, needles, bark, cones, and so on) known as clean chip residual that remains after pine trees are harvested for pulp wood.

Gruda and Schnitzler (1999) reported that growth of tomatoes in a $100 \%$ wood substrate was comparable to a peat substrate if the wood substrate was impregnated with $\mathrm{N}$ during manufacturing or when extra $\mathrm{N}$ was added during cultivation. Wright et al. (2008) also showed that mums (Chrysanthemum xgrandiflora Tzvelev. 'Baton Rouge') can be grown in PTS as well as in a commercial peat substrate when an additional $100 \mathrm{ppm} \mathrm{N}$ was given to PTS-grown plants. Based on these observations, additional fertilizer (primarily $\mathrm{N}$ ) is needed for plant production when growing in a wood-based substrate. The goal of a fertility program is to maintain an optimal level of nutrients in the substrate throughout the growing season while limiting nutrient loss from the container. As a result of an increased awareness of and attention to environmental contamination from nursery runoff sites, growers and researchers are working to precisely manage fertility of container substrates during production to minimize nutrient losses while continuing to maximize plant growth. Therefore, the purpose of this research was to study the effect of fertilizer rate on growth of japanese holly and azalea in PTS compared with PB to begin development of an efficient fertility management program for growing plants in PTS. A fertility management program will allow plant growth in PTS to be maximized at the lowest fertilizer rate possible while minimizing nutrient waste and loss.

\section{Materials and Methods}

2005 study. On 17 Aug. 2005, japanese holly liners (10-cm tall in $64-\mathrm{cm}^{3}$ containers) were potted in 2.8-L plastic containers [17 $\mathrm{cm}(\mathrm{h}) \times 17 \mathrm{~cm}(\mathrm{~d})]$ containing either PB or PTS. Pine tree substrate was produced from loblolly pine trees $(\approx 30 \mathrm{~cm}$ basal diameter) that were harvested at ground level and delimbed on 25 July 2005 in Warsaw, VA. Trees were then chipped (including bark) with a Morbark Chipper (Winn, MI) operated by Wood Preservers Inc. (Warsaw, VA) on 26 July 2005 . Wood chips $(2.5 \mathrm{~cm} \times 2.5 \mathrm{~cm} \times$ $0.5 \mathrm{~cm})$ were further ground in a hammer mill (Meadows Mills, Inc., North Wilkesboro, NC) on 27 July 2005 to pass through a $6.35-\mathrm{mm}$ screen. Pine tree substrate was used fresh (uncomposted) and amended with 0.6 $\mathrm{kg} \cdot \mathrm{m}^{-3}$ calcium sulfate $\left(\mathrm{CaSO}_{4}\right)$ based on previous work by Saunders et al. (2005) that showed improved growth in herbaceous species when $\mathrm{CaSO}_{4}$ was incorporated in PTS. No preplant amendments are required with
PB for japanese holly production. Osmocote Plus (15N-3.9P-10K; O.M. Scott Horticulture Products) was preplant-incorporated in PB and PTS at rates of $3.5,5.9,8.3$, or 10.6 $\mathrm{kg} \cdot \mathrm{m}^{-3}\left(5.3,8.9,12.5\right.$, or $16 \mathrm{~g} \cdot \mathrm{m}^{-3}$ of $\left.\mathrm{N}\right)$, respectively. Plants were grown on benches in a greenhouse in Blacksburg, VA, and irrigated as needed with beaker-applied water to achieve an approximate $30 \%$ leaching fraction. Average day and night temperatures in the greenhouse were 26 and $22{ }^{\circ} \mathrm{C}$, respectively. Substrate solution was extracted using the pourthrough method (Wright, 1986) every 4 weeks and analyzed for $\mathrm{pH}$ and EC using a Hanna HI 9811 instrument (Hanna Instruments, Woonsocket, RI). Nutrient analysis was conducted on substrate solution taken on 7 Oct. 2005 and analyzed for nitrate $\left(\mathrm{NO}_{3}-\mathrm{N}\right)$ with an Orion ion selective electrode (Thermo Electron, Beverly, MA) and $\mathrm{P}, \mathrm{K}, \mathrm{Ca}$, and $\mathrm{Mg}$ concentrations were determined with a Spectro Ciros Vision ICP (Spectro Analytical Instrument, Mahwah, NJ). On 22 Nov., shoots were severed at the substrate surface and roots were washed, dried at $65^{\circ} \mathrm{C}$ for $4 \mathrm{~d}$, and weighed. Samples of the most recently matured leaves from four plants per treatment were harvested and analyzed for N, P, and K (Quality Analytical Laboratories, Panama City, FL).

As a measure of microbial activity in $\mathrm{PB}$ and PTS, substrate $\mathrm{CO}_{2}$ efflux levels were determined as an indicator of the potential for $\mathrm{N}$ immobilization to occur (Wang et al., 2003). Substrate $\mathrm{CO}_{2}$ efflux ( $\mu \mathrm{mol} \mathrm{CO}_{2}$ $\left.\mathrm{m}^{-2} \cdot \mathrm{s}^{-1}\right)$ was determined at the end of the experiment (23 Nov. 2005) on three container replications of both substrates at each fertilizer rate using a LI-6400 (LI-COR, Lincoln, $\mathrm{NE}$ ) fitted with a soil $\mathrm{CO}_{2}$ flux chamber designed to take nondestructive $\mathrm{CO}_{2}$ measurements from the substrate-filled containers. A $10.2-\mathrm{cm}$ diameter $\times 5.1-\mathrm{cm}$ high plastic collar was inserted $0.5 \mathrm{~cm}$ into the container substrate surface allowing the soil $\mathrm{CO}_{2}$ flux chamber to be inserted and positioned securely above the substrate surface for $\mathrm{CO}_{2}$ efflux measurements.

Physical properties including air space, container capacity, total porosity, and bulk density were determined on three replicate samples of each substrate at the beginning of the experiment using the North Carolina State University Porometer method as described by Fonteno et al. (1995). Cation exchange capacity (CEC) was determined by A \& L Eastern Laboratories (Richmond, VA) using the AOAC International Official Method (Thrope, 1973).

2007 study. An experiment similar to the previous experiment was conducted from 1 Mar. to 25 May 2007. Pine tree substrate was produced from 12-year-old loblolly pine trees $(\approx 25 \mathrm{~cm}$ in basal diameter) that were harvested at ground level and delimbed on 19 Feb. 2007 in Blackstone, VA, and chipped with bark intact on 20 Feb. 2007 with a Bandit Chipper (Model 200; Bandit Industries, Inc., Remus, MI). Wood chips were then further ground in a hammer mill on 21 Feb. 2007 to pass through a $6.35-\mathrm{mm}$ screen.
Physical properties of both substrates were determined using the method described in the 2005 study. Osmocote Plus (15N-3.9P-10K) was incorporated in PB and PTS at rates of $3.5,5.9,8.3$, or $10.6 \mathrm{~kg} \cdot \mathrm{m}^{-3}(5.3,8.9,12.5$, or $16 \mathrm{~g} \cdot \mathrm{m}^{-3}$ of $\left.\mathrm{N}\right)$, respectively. In addition to japanese holly, this experiment also included azalea. Because azaleas require lower fertilizer rates (compared with holly) for optimal growth (Yeager et al., 2007), this species was included in this study to provide growth data on a woody species with a relatively low nutrient requirement when grown in PB and PTS. Fertilizer rates for azalea were 1.2, 3.5, 5.9 , and $8.3 \mathrm{~kg} \cdot \mathrm{m}^{-3}\left(1.8,5.3,8.9\right.$, or $12 \mathrm{~g} \cdot \mathrm{m}^{-3}$ of $\mathrm{N}$ ), respectively. Both substrates were preplant amended similar to the 2005 study. Plants were grown on a gravel ground bed in a greenhouse in Blacksburg, VA, and overhead-irrigated at a rate of $4.5 \mathrm{~cm} \cdot \mathrm{h}$ with a Basic Grower boom sprayer (McConkey Co., Sumer, WA) as needed to achieve an approximate $30 \%$ leaching fraction. Species were grouped separately on the ground bed and irrigated independently during the entire experiment. Substrate solution was extracted using the PT method every 2 weeks and analyzed for $\mathrm{pH}$ and EC for both species. Nutrient analysis was conducted on substrate solution taken from each species on $30 \mathrm{Apr}$. 2007 in the same method as previously described for the 2005 study. On 25 May 2007 , shoots of both species were severed at the substrate surface and the roots of japanese holly were washed, dried at $65{ }^{\circ} \mathrm{C}$ for $4 \mathrm{~d}$, and weighed. Samples of the most recently matured leaves from five plants, per treatment, per species were harvested and analyzed for N, P, and K by the Penn State Analytical Testing Laboratory, University Park, PA. Substrate $\mathrm{CO}_{2}$ efflux was measured on three container replications of each treatment for japanese holly.

The experimental design was completely randomized with six single container replications per treatment in 2005 and five replications per treatment per species in 2007. All data in both studies were analyzed with the analysis of variance procedure using SAS (version 9.1; SAS Institute, Cary, NC) and subjected to regression analysis using SigmaPlot (version 9.01; SPSS, Chicago, IL) with the exception that substrate physical properties were subjected to analysis of variance within the GLM procedure with treatment means separated by least significant difference analysis. Standard error bars are presented in Figures 1 through 3 with the linear and quadratic regression responses presented.

\section{Results and Discussion}

2005 study. There was a significant substrate $\times$ fertilizer rate interaction $(P \leq 0.001)$ for shoot dry weight: at fertilizer rates of 3.5 and $5.9 \mathrm{~kg} \cdot \mathrm{m}^{-3}$, shoot dry weight was higher for PB than PTS; at $8.3 \mathrm{~kg} \cdot \mathrm{m}^{-3}$, dry weight was approximately equal for the two substrates; at $10.6 \mathrm{~kg} \cdot \mathrm{m}^{-3}$, dry weight was higher for PTS than PB (Fig. 1A). Root dry weights were not influenced by fertilizer rate $(P \leq$ 


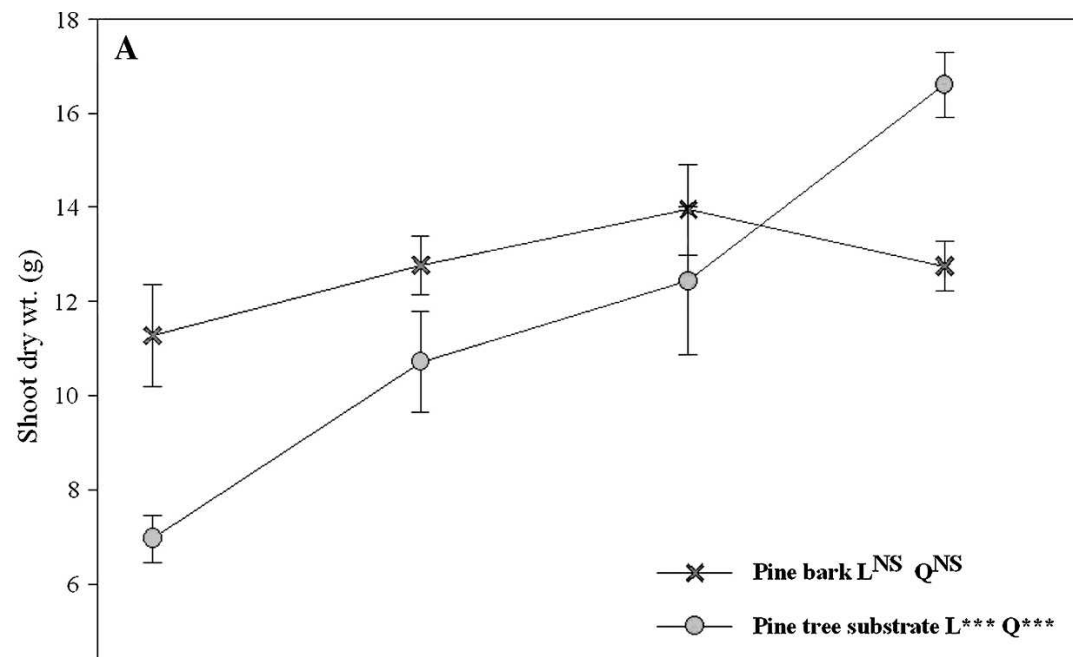

B

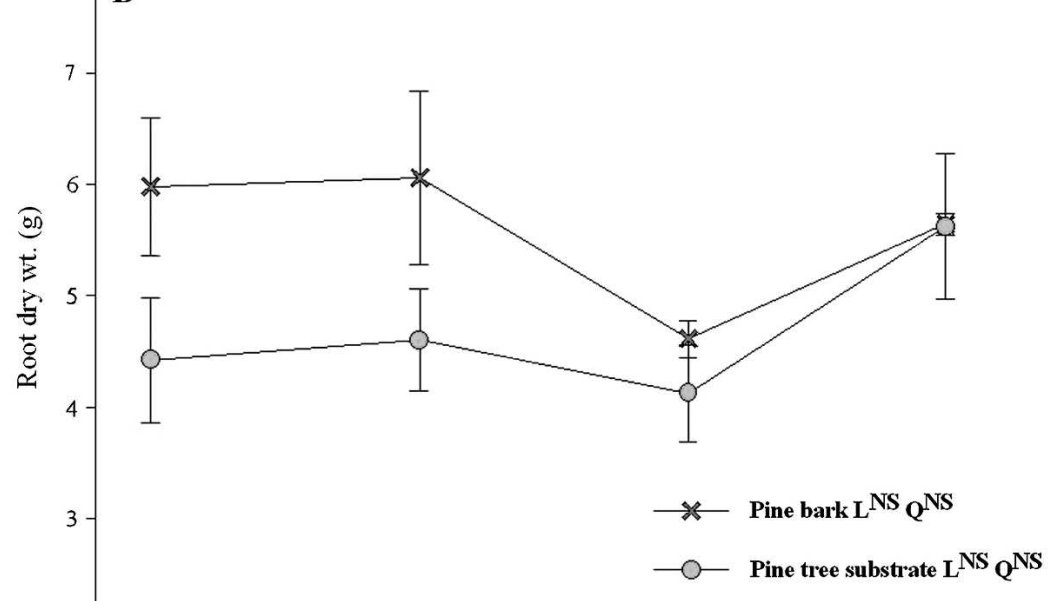

C

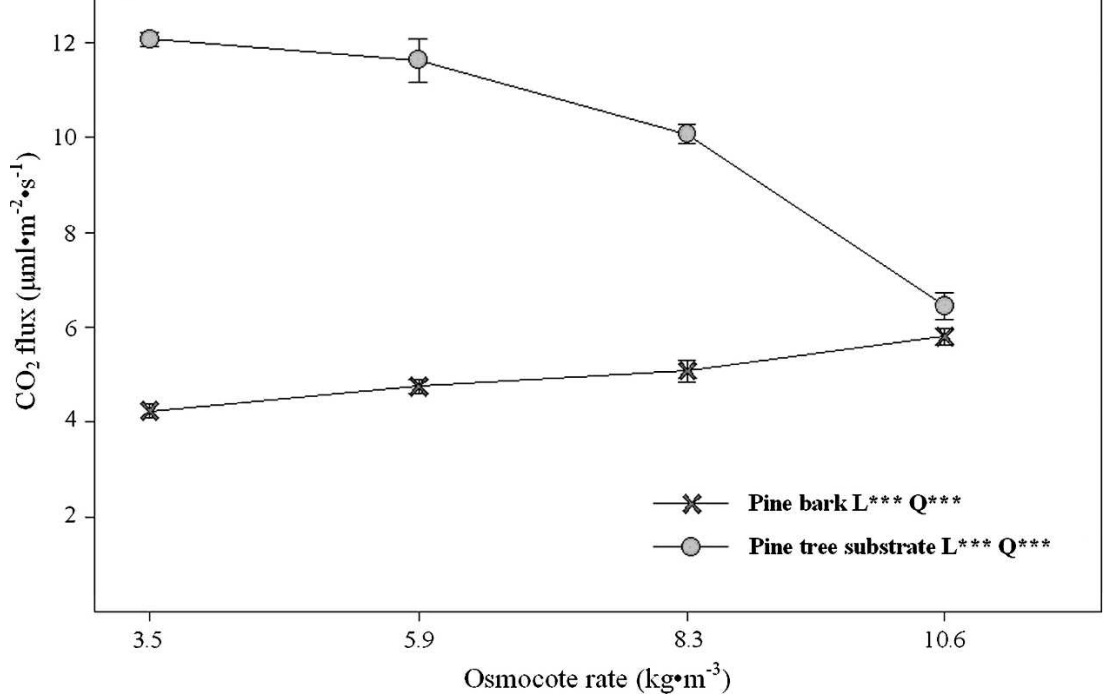

Fig. 1. (A) (2005 study) Shoot dry weight (pine bark: $y=13.3930(1-0.5364 \mathrm{x}), R^{2}=0.16$ and pine tree substrate: $\left.\mathrm{y}=3.3072+0.6071 \mathrm{x}-0.0066 \mathrm{x}^{2}, R^{2}=0.67\right) ;(\mathbf{B})$ root dry weight (pine bark: $\mathrm{y}=8.1313$ $0.4120 \mathrm{x}+0.0146 \mathrm{x}^{2}, R^{2}=0.12$ and pine tree substrate: $\left.\mathrm{y}=7.3761-0.3766 \mathrm{x}+0.0112 \mathrm{x}^{2}, R^{2}=0.23\right) ;(\mathbf{C})$ substrate $\mathrm{CO}_{2}$ efflux rates $\left(\mu \mathrm{mol} \mathrm{CO} \mathrm{C}^{-2} \cdot \mathrm{s}^{-1}\right)$ (pine bark: $\mathrm{y}=3.9333+0.0594 \mathrm{x}+0.0108 \mathrm{x}^{2}, R^{2}=0.54$ and pine tree substrate: $\left.\mathrm{y}=9.3141+1.2809 \mathrm{x}-0.1458 \mathrm{x}^{2}, R^{2}=0.87\right)$ of japanese holly grown from 17 Aug. 2005 to 22 Nov. 2005 in pine bark (x) or pine tree substrate $(O)$ incorporated with four rates of Osmocote Plus $15 \mathrm{~N}-3.9 \mathrm{P}-10 \mathrm{~K}$. Each point represents the means \pm SE indicated by SE bars $(\mathrm{n}=5)$. $\mathrm{L}=$ linear; $\mathrm{Q}=$ quadratic responses, nonsignificant (Ns), or significant at $P \leq 0.05(*), 0.01(* *)$, or $0.001(* * *)$, respectively.
$0.145)$ but were higher in PB than PTS at the 3.5 and $5.9 \mathrm{~kg} \cdot \mathrm{m}^{-3}$ rates and equal in both substrates at the 8.3 and $10.6 \mathrm{~kg} \cdot \mathrm{m}^{-3}$ rates (Fig. 1B). There was a significant substrate $\times$ fertilizer rate interaction $(P \leq 0.002)$ for substrate $\mathrm{CO}_{2}$ efflux. Efflux levels were higher in PTS than in PB at each fertilizer rate with the magnitude of difference decreasing as fertilizer rate increased (Fig. 1C). At the lowest fertilizer rate $\left(3.5 \mathrm{~kg} \cdot \mathrm{m}^{-3}\right)$, substrate efflux levels in PTS were four times higher than in PB but were nearly the same at the highest fertilizer rate $\left(10.6 \mathrm{~kg} \cdot \mathrm{m}^{-3}\right)$. In contrast to PTS, substrate efflux levels slightly increased in the PB substrate as fertilizer rates increased, resulting in similar efflux levels at the highest fertilizer rate (Fig. 1C).

Substrate solution EC values increased with increasing fertilizer rate and at any particular fertilizer rate levels were higher in PB than in PTS (Table 1), showing that higher fertilizer rates were required for PTS compared with $\mathrm{PB}$ to achieve comparable substrate EC levels. Substrate solution $\mathrm{pH}$ was higher in PTS at each fertilizer rate compared with $\mathrm{PB}$ and decreased as fertilizer rate increased (Table 1). The $\mathrm{pH}$ of $\mathrm{PB}$ did not change with increasing fertilizer rates. There was a significant substrate and fertilizer rate response for all nutrient concentrations (except for $\mathrm{K}$ ) in the substrate solution sampled on 7 Oct. 2005 (Table 2). Similar to the EC levels previously discussed, nitrate $\left(\mathrm{NO}_{3}-\mathrm{N}\right)$ concentrations were higher in $\mathrm{PB}$ at each fertilizer rate compared with PTS. Solution concentrations of $\mathrm{P}, \mathrm{K}, \mathrm{Ca}$, and $\mathrm{Mg}$ were also higher in $\mathrm{PB}$ compared with PTS (Table 2).

Leaf tissue nutrient concentrations were generally higher in PB-grown plants compared with PTS-grown plants at each fertilizer rate (Table 3). All nutrient levels generally increased as fertilizer rate increased for $\mathrm{PB}$ up to the $10.6 \mathrm{~kg} \cdot \mathrm{m}^{-3}$ rate, and nutrient levels increased in PTS plants up to the $8.3 \mathrm{~kg} \cdot \mathrm{m}^{-3}$ rate (Table 3 ). Tissue $\mathrm{N}$ levels in PB-grown plants were above the recommended sufficiency range of $1.80 \%$ to $2.80 \%$ (Mills and Jones, 1996) at all fertilizer rates, and tissue $\mathrm{N}$ levels in PTS-grown plants were within the recommended range at the $5.9,8.3$, and $10.6 \mathrm{~kg} \cdot \mathrm{m}^{-3}$ fertilizer rates (Table 3).

Total porosity was similar for both PB and PTS and was within the recommended range outlined in The Best Management Practices Guide for Producing Container-Grown Plants (BMP) for physical properties of container substrates (Yeager et al., 2007) (Table 4). Air space was significantly higher in PTS $(38.2 \%)$ than in PB and was above the recommended BMP range. Container capacity was higher in PB $(56.1 \%)$ than in PTS (45.2\%), but both were within the BMP range (45\% to $65 \%)$ for both substrates. Bulk density of PTS was similar to PB but was below minimum recommended value of $0.19 \mathrm{~g} \cdot \mathrm{cm}^{-3}$ (Table 4).

2007 study. Like with the 2005 experiment, there was a significant substrate $x$ 


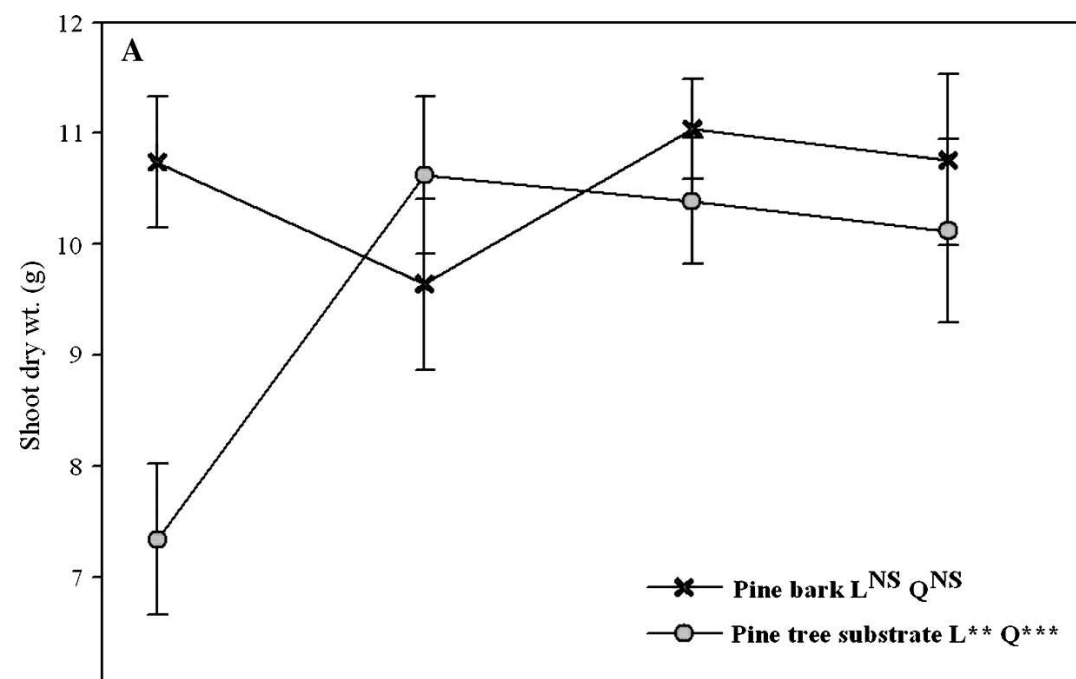

B

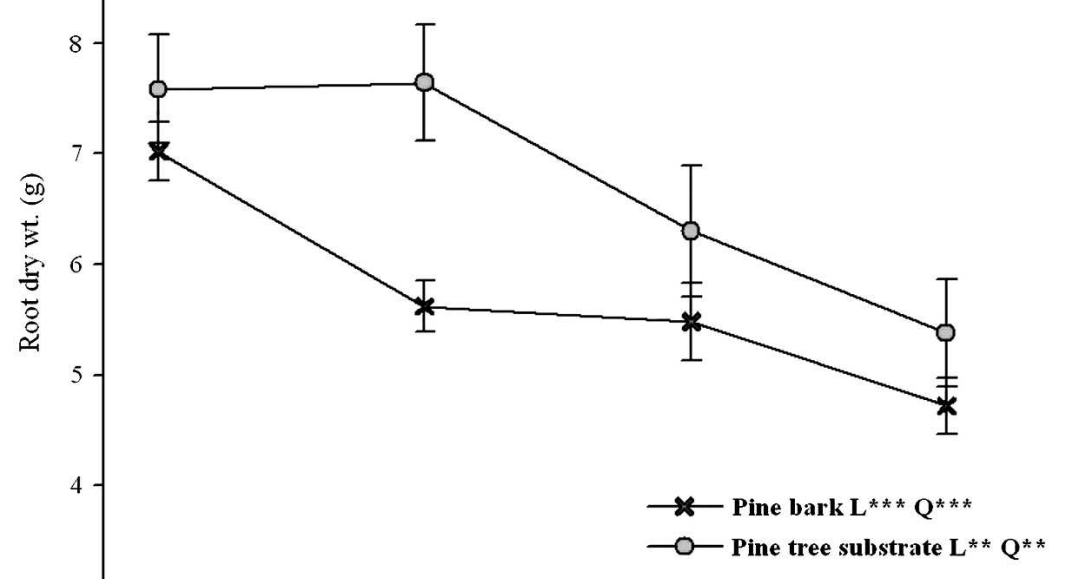

C

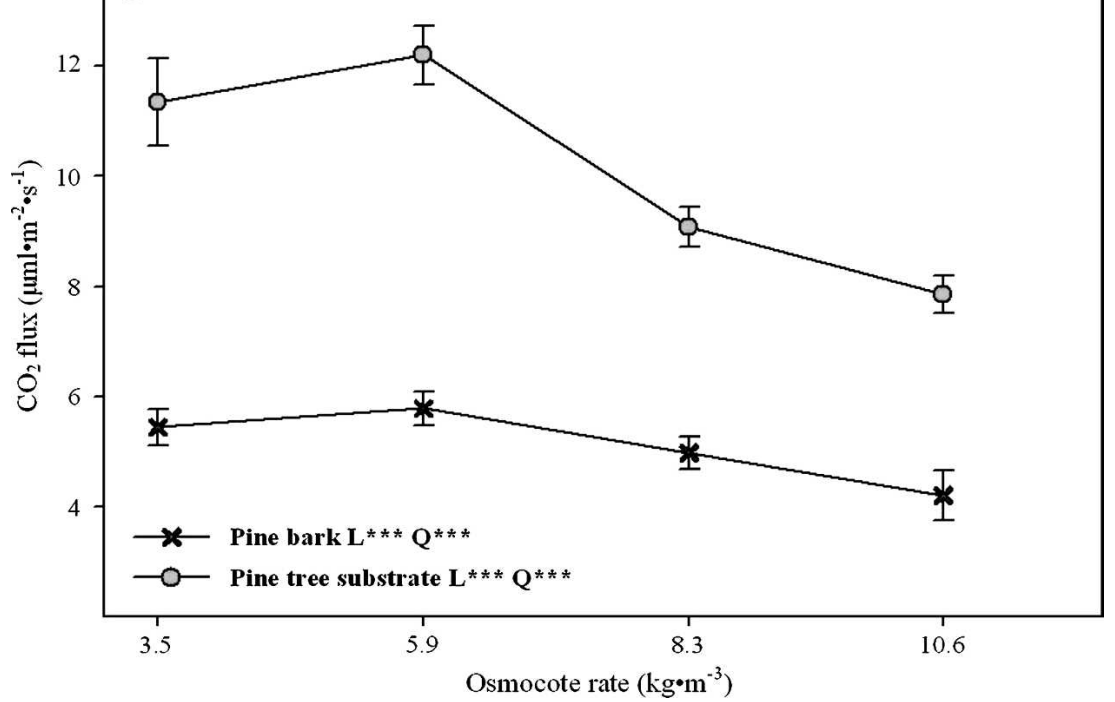

Fig. 2. (A) (2007 study) Shoot dry weight [pine bark: $y=11.7374+0.4768 x-0.0382 x^{2}, R^{2}=0.04$ and pine tree substrate: $\left.\left.\mathrm{y}=-369,167.4+269,177.8(1-0.0385 \mathrm{x}), R^{2}=0.79\right)\right] ;(\mathbf{B})$ root dry weight (pine bark: $\mathrm{y}=$ $9.0014-0.6902 \mathrm{x}+0.0279 \mathrm{x}^{2}, R^{2}=0.65$ and pine tree substrate: $\mathrm{y}=7.1347-0.3125 \mathrm{x}+0.0459 \mathrm{x}^{2}, R^{2}=$ 0.43 ); (C) substrate $\mathrm{CO}_{2}$ efflux rates $\left(\mu \mathrm{mol} \mathrm{CO} \mathrm{Cm}^{-2} \cdot \mathrm{s}^{-1}\right)$ (pine bark: $\mathrm{y}=4.8700+0.3601 \mathrm{x}+0.0459 \mathrm{x}^{2}$ $R^{2}=0.62$ and pine tree substrate: $\left.\mathrm{y}=10.0108+0.8013 \mathrm{x}+0.0974 \mathrm{x}^{2}, R^{2}=0.62\right)$ of japanese holly grown from 1 Mar. 2007 to 25 May 2007 in pine bark $(x)$ or pine tree substrate $(O)$ incorporated with four rates of Osmocote Plus $15 \mathrm{~N}-3.9 \mathrm{P}-10 \mathrm{~K}$. Each point represents the means $\pm \mathrm{SE}$ indicated by SE bars $(\mathrm{n}=5)$. $\mathrm{L}$ $=$ linear; $\mathrm{Q}=$ quadratic responses, nonsignificant $(\mathrm{NS})$, or significant at $P \leq 0.05\left(^{*}\right), 0.01\left(^{* *}\right)$, or $0.0001(* * *)$, respectively. fertilizer rate interaction $(P \leq 0.025)$ for japanese holly shoot dry weight: at the fertilizer rate of $3.5 \mathrm{~kg} \cdot \mathrm{m}^{-3}$, shoot dry weight was higher for PB than PTS; at rates of 5.9, 8.3 , and $10.6 \mathrm{~kg} \cdot \mathrm{m}^{-3}$, dry weight was similar for PB and PTS plants (Fig. 2A). The data also indicate that maximum shoot dry weight for japanese holly in PB is at $3.5 \mathrm{~kg} \cdot \mathrm{m}^{-3}$ or less, and for PTS is between the 3.5 and 5.9 $\mathrm{kg} \cdot \mathrm{m}^{-3}$ rates (Fig. 2A).

There was a substrate $\times$ rate interaction for japanese holly root dry weights $(P \leq$ 0.017). Root growth in both PTS and PB decreased as fertilizer rate increased (Fig. 2B), but in contrast to 2005 , root growth was generally higher in PTS-grown plants than PB-grown plants. There was a significant substrate $\times$ fertilizer rate interaction $(P \leq$ 0.001 ) for substrate $\mathrm{CO}_{2}$ efflux. Similar to 2005 results, substrate $\mathrm{CO}_{2}$ efflux levels were higher in PTS than in PB at each fertilizer rate with the magnitude of difference decreasing slightly as fertilizer rate increased (Fig. 2C). At all fertilizer rates $(3.5,5.9,8.3$, and 10.6 $\left.\mathrm{kg} \cdot \mathrm{m}^{-3}\right)$, substrate $\mathrm{CO}_{2}$ efflux levels were twice as high in PTS as in PB (Fig. 2C). Like with the 2005 experiment, substrate solution EC levels increased with increasing fertilizer rates in both substrates (Table 1). Also similar to 2005 , substrate solution $\mathrm{pH}$ was higher in PTS than PB regardless of fertilizer rate, and $\mathrm{pH}$ decreased with increasing fertilizer rate in PB and PTS (Table 1). Similar to the 2005 data, nitrate concentrations in the substrate solution were generally higher in PB compared with PTS and substrate solution concentrations of $\mathrm{P}, \mathrm{K}, \mathrm{Ca}$, and $\mathrm{Mg}$ were in most cases higher in PB compared with PTS (Table 2). Similar to 2005, japanese holly leaf tissue nutrient levels generally increased in response to increasing fertilizer rate for $\mathrm{PB}$ and PTS-grown plants (Table 3). In contrast to 2005 data, leaf nutrient levels at the 8.3 and $10.6 \mathrm{~kg} \cdot \mathrm{m}^{-3}$ fertilizer rates for $\mathrm{N}$ and at the $5.9,8.3$, and $10.6 \mathrm{~kg} \cdot \mathrm{m}^{-3}$ rates for $\mathrm{P}$ (Table 3 ) were higher in PTS-grown plants compared with PB-grown plants. Tissue $\mathrm{N}$ levels were above the recommended sufficiency range $(1.8 \%$ to $2.8 \%)$ at all fertilizer rates for plants grown in both substrates except for the 3.5 $\mathrm{kg} \cdot \mathrm{m}^{-3}$ rate in PTS. Potassium levels were higher in PTS-grown plants at all fertilizer rates (Table 3). Physical property data of PTS and PB in 2007 were similar to 2005 data and therefore are not reported.

There was a significant substrate $\times$ fertilizer rate interaction $(P \leq 0.013)$ for azalea shoot dry weight: at the fertilizer rates of 1.2 and $3.5 \mathrm{~kg} \cdot \mathrm{m}^{-3}$, shoot dry weight was higher for PB than PTS; at rates 5.9 and $8.3 \mathrm{~kg} \cdot \mathrm{m}^{-3}$, dry weights were similar for PB and PTS plants (Fig. 3) with maximum shoot dry weight occurring at $3.5 \mathrm{~kg} \cdot \mathrm{m}^{-3}$ for $\mathrm{PB}$ and at $5.9 \mathrm{~kg} \cdot \mathrm{m}^{-3}$ for PTS. Substrate solution EC levels for azalea increased with increasing fertilizer rate in both substrates and were higher in PB than in PTS at all rates (Table 5). This once again shows that higher fertilizer rates are required in PTS compared with $\mathrm{PB}$ to achieve similar substrate EC levels. Similar to japanese holly, substrate solution $\mathrm{pH}$ 


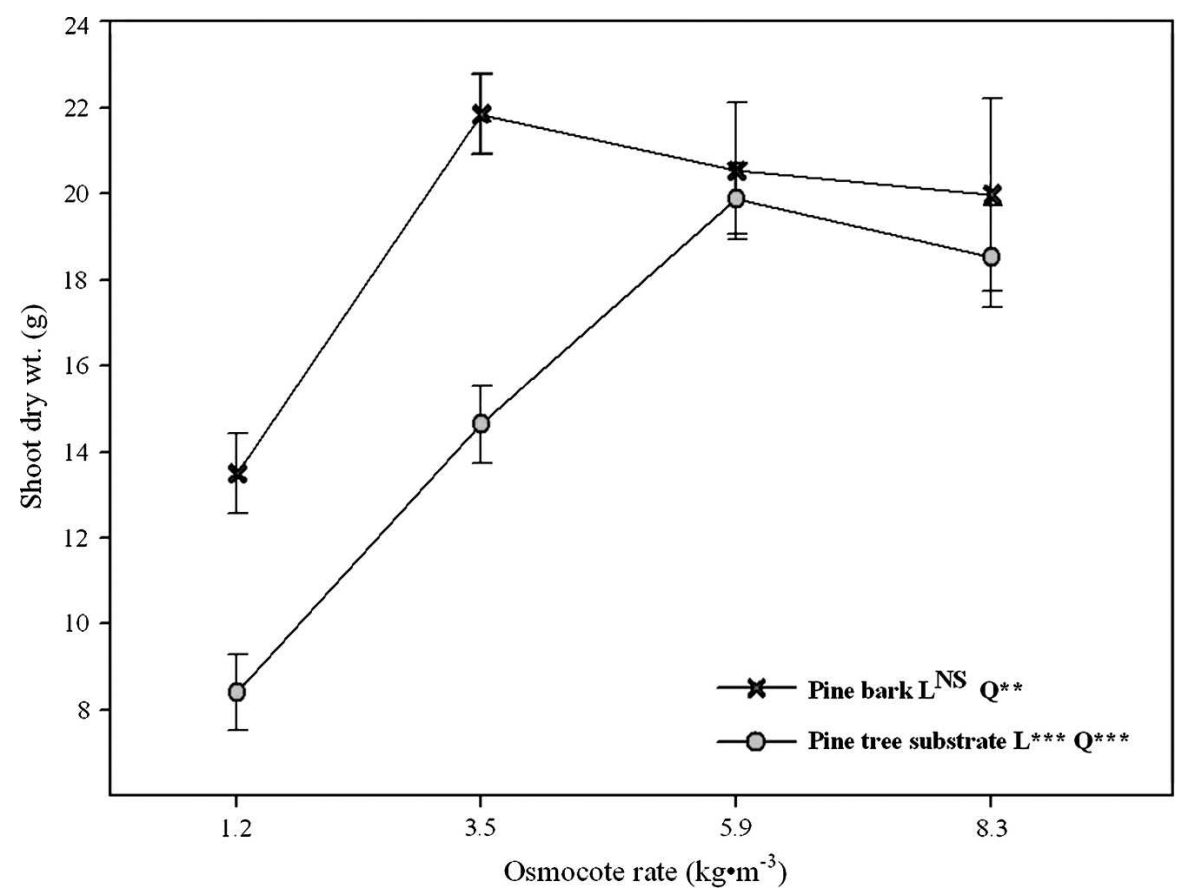

Fig. 3. (2007 study) Shoot dry weight (pine bark: $\mathrm{y}=20.1497(1-0.5475 \mathrm{x}), R^{2}=0.40$ and pine tree substrate: $\mathrm{y}=3.0218+2.7865 \mathrm{x}-0.1184 \mathrm{x}^{2}, R^{2}=0.83$ ) of azalea grown from 1 Mar. 2007 to 25 May 2007 in pine bark $(\mathrm{x})$ or pine tree substrate $(\mathrm{O})$ incorporated with four rates of Osmocote Plus $15 \mathrm{~N}-$ 3.9P-10K. Each point represents the means \pm SE indicated by SE bars $(n=5) . \mathrm{L}=$ linear; $\mathrm{Q}=$ quadratic responses, nonsignificant (NS), or significant at $P \leq 0.05(*), 0.01(* *)$, or $0.001(* * *)$.

Table 1. Average electrical conductivity (EC) levels and $\mathrm{pH}$ values of substrate solution for japanese holly grown in pine bark or pine tree substrates for 3 months when fertilized with four rates of Osmocote Plus $15 \mathrm{~N}-3.9 \mathrm{P}-10 \mathrm{~K}^{2}$.

\begin{tabular}{|c|c|c|c|c|}
\hline \multirow{2}{*}{$\begin{array}{l}\text { Treatment } \\
\text { Osmocote }\left(\mathrm{kg} \cdot \mathrm{m}^{-3}\right)\end{array}$} & \multicolumn{2}{|c|}{2005 study $(n=3)$} & \multicolumn{2}{|c|}{2007 study $(\mathrm{n}=6)$} \\
\hline & $\mathrm{pH}$ & $\mathrm{EC}\left(\mathrm{dS} \cdot \mathrm{m}^{-3}\right)^{\mathrm{y}}$ & $\mathrm{pH}$ & $\mathrm{EC}\left(\mathrm{dS} \cdot \mathrm{m}^{-3}\right)$ \\
\hline \multicolumn{5}{|l|}{ Pine bark } \\
\hline 3.5 & 3.6 & 0.56 & 4.43 & 1.15 \\
\hline 5.9 & 3.2 & 1.50 & 4.27 & 1.58 \\
\hline 8.3 & 3.3 & 2.06 & 4.20 & 2.14 \\
\hline 10.6 & 3.3 & 2.11 & 4.32 & 2.47 \\
\hline \multirow[t]{2}{*}{ Significance $^{\mathrm{xw}}$} & NS & $\mathrm{L}^{* * *}$ & $\mathrm{~L}^{* * *}$ & $\mathrm{~L}^{* * *}$ \\
\hline & $\mathrm{Q}^{* *}$ & $\mathrm{Q}^{* * *}$ & $\mathrm{Q}^{* * *}$ & $\mathrm{Q}^{* * *}$ \\
\hline \multicolumn{5}{|l|}{ Pine tree substrate ${ }^{v}$} \\
\hline 3.5 & 5.2 & 0.27 & 5.70 & 0.62 \\
\hline 5.9 & 4.8 & 0.40 & 5.60 & 1.00 \\
\hline 8.3 & 4.1 & 1.20 & 5.27 & 1.53 \\
\hline 10.6 & 4.0 & 1.26 & 4.95 & 2.52 \\
\hline \multirow[t]{2}{*}{ Significance } & $\mathrm{L}^{* * *}$ & $\mathrm{~L}^{* * *}$ & $\mathrm{~L}^{* * *}$ & $\mathrm{~L}^{* * *}$ \\
\hline & $\mathrm{Q}^{* *}$ & $\mathrm{Q}^{* * *}$ & $\mathrm{Q}^{* * *}$ & $\mathrm{Q}^{* *}$ \\
\hline Substrate & 0.0001 & 0.0001 & 0.0001 & 0.2152 \\
\hline Fertilizer rate & 0.0004 & 0.0001 & 0.0001 & 0.0001 \\
\hline Substrate $\times$ fertilizer rate & 0.0047 & 0.0789 & 0.0001 & 0.0001 \\
\hline
\end{tabular}

${ }^{\mathrm{z}} \mathrm{pH}$ and electrical conductivity (EC) of substrate solution obtained by the pourthrough method (Wright, 1986).

${ }^{\mathrm{y}} 1 \mathrm{dS} \cdot \mathrm{m}^{-3}=1 \mathrm{mmho} / \mathrm{cm}$.

${ }^{\mathrm{x}}$ Nonsignificant (NS) or significant at $P \leq 0.05(*), 0.01(* *)$, or $0.001(* * *)$, respectively.

${ }^{\mathrm{w}} \mathrm{L}=$ linear; $\mathrm{Q}=$ quadratic response for concentration at $*, * *$, or $* * *$.

"Pine tree substrate produced from 12-year-old loblolly pine trees harvested at ground level, delimbed, chipped, and hammer milled to pass through a 6.35 -mm screen.

was higher in PTS than PB regardless of fertilizer rate (Table 5). $\mathrm{pH}$ decreased in $\mathrm{PB}$ as fertilizer rate increased in contrast to $\mathrm{pH}$ values of PTS that did not change with fertilizer rate (Table 5). Substrate solution nitrate concentrations increased with increasing fertilizer rate in both substrates and were lower in PTS compared with PB at each fertilizer rate (Table 5). Substrate solution $\mathrm{P}$ tions increased with fertilizer up to the 5.9 $\mathrm{kg} \cdot \mathrm{m}^{-3}$ rate. Tissue $\mathrm{N}$ concentrations were higher in PB than in PTS at all fertilizer rates. Tissue $\mathrm{N}$ concentrations were within the sufficiency range $(2.0 \%$ to $3.0 \%)$ (Mills and Jones, 1996) for PB plants at the 3.5, 5.9, and $8.3 \mathrm{~kg} \cdot \mathrm{m}^{-3}$ fertilizer rates, but only at the 5.9 and $8.3 \mathrm{~kg} \cdot \mathrm{m}^{-3}$ rates for PTS plants.

This study demonstrates that a higher rate of fertilizer is required for japanese holly and azalea to achieve shoot growth in PTS comparable to shoot growth in PB. Both japanese holly and azalea achieved shoot growth in PTS comparable to shoot growth in PB with $\approx 2.4 \mathrm{~kg} \cdot \mathrm{m}^{-3}$ additional fertilizer for PTS. For example, shoot growth of japanese holly was similar at $5.9 \mathrm{~kg} \cdot \mathrm{m}^{-3}$ in $\mathrm{PB}$ and $8.3 \mathrm{~kg} \cdot \mathrm{m}^{-3}$ in PTS in 2005 (Fig. 1A) and shoot growth was similar at $3.5 \mathrm{~kg} \cdot \mathrm{m}^{-3}$ in $\mathrm{PB}$ and $5.9 \mathrm{~kg} \cdot \mathrm{m}^{-3}$ in PTS in 2007 (Fig. 2A). The different growth response in japanese holly to fertilizer rate in 2005 versus 2007 may be attributable in some way to the seasonal effects (light and temperature differences effecting irrigation need and frequency) between the fall (2005) and spring (2007) experiments. In addition, the placement of the 2007 study on graveled ground beds of the greenhouse instead of on benchtops (2005 study) may have resulted in less air circulation and decreased drying of the containers resulting in a lesser need for water. Lower irrigation rates and frequency in 2007 could have reduced the amount of nutrient leaching from the substrates and resulted in higher substrate EC averages, which occurred in 2007 compared with 2005 (Table 1). Niemiera and Leda (1993) showed $\mathrm{N}\left(\mathrm{NO}_{3}-\mathrm{N}\right.$ and $\left.\mathrm{NH}_{4}-\mathrm{N}\right)$ leaching in a $\mathrm{PB}$ substrate increases with increasing leaching fraction (irrigation volume) resulting in lower substrate solution EC levels and lower concentrations of substrate solution N. In contrast, a lower leaching fraction (less irrigation volume) causes less nutrient leaching and results in higher substrate solution EC levels and $\mathrm{N}$ concentrations. Their results help to explain the higher EC levels reported in the 2007 study, which received generally lower and less frequent irrigation applications. The higher EC levels in 2007 than in 2005 are likely the reason for higher tissue $\mathrm{N}$ concentrations at all fertilizer rates for plants grown in both PB and PTS in 2007 (Table 3). Higher tissue $\mathrm{N}$ concentrations at lower fertilizer rates in 2007 could explain the increased growth response in japanese holly at lower fertilizer rates compared with plants grown in 2005.

Maximum shoot growth of azalea occurred at the same fertilizer rates (3.5 $\mathrm{kg} \cdot \mathrm{m}^{-3}$ for PB and $5.9 \mathrm{~kg} \cdot \mathrm{m}^{-3}$ for PTS; Fig. $3)$ as japanese holly in 2007, which was unexpected because azalea is considered a woody plant with lower nutrient requirements compared with japanese holly. The substrate solution EC levels and nutrient concentrations for azalea plants grown in PB and PTS were generally lower (Table 5) at the same fertilizer rates $(3.5,5.9$, and 8.3 $\mathrm{kg} \cdot \mathrm{m}^{-3}$ ) compared with levels seen in the substrate solution of japanese holly plants 
Table 2. Substrate solution nutrient concentrations sampled on 7 Oct. 2005 and 20 Apr. 2007 for japanese holly grown in pine bark or pine tree substrate fertilized with four rates of Osmocote Plus $15 \mathrm{~N}-3.9 \mathrm{P}-10 \mathrm{~K}^{2}$.

\begin{tabular}{|c|c|c|c|c|c|c|c|c|c|c|}
\hline \multirow{2}{*}{$\begin{array}{l}\text { Treatment } \\
\text { Osmocote }\left(\mathrm{kg} \cdot \mathrm{m}^{-3}\right)\end{array}$} & \multicolumn{5}{|c|}{2005} & \multicolumn{5}{|c|}{2007} \\
\hline & $\overline{\mathrm{NO}_{3}-\mathrm{N}}$ & $P$ & $\mathrm{~K}$ & $\mathrm{Ca}$ & $\mathrm{Mg}$ & $\mathrm{NO}_{3}-\mathrm{N}$ & $P$ & $\mathrm{~K}$ & $\mathrm{Ca}$ & $\mathrm{Mg}$ \\
\hline \multicolumn{11}{|l|}{ Pine bark } \\
\hline 5.9 & 90.5 & 23.5 & 161.5 & 75.5 & 28.8 & 75.4 & 29.6 & 171.0 & 65.2 & 27.7 \\
\hline 8.3 & 125.5 & 35.3 & 203.8 & 99.0 & 38.5 & 115.9 & 37.5 & 188.0 & 54.4 & 33.2 \\
\hline 10.6 & 128.5 & 42.3 & 205.5 & 87.0 & 35 & 129.0 & 68.1 & 288.9 & 74.4 & 45.2 \\
\hline Significance $^{\mathrm{xw}}$ & $\mathrm{L}^{* * *}$ & $\mathrm{~L}^{* * *}$ & $\mathrm{~L}^{* * *}$ & $\mathrm{~L}^{* * *}$ & $\mathrm{~L}^{* * *}$ & $\mathrm{~L}^{* * *}$ & $\mathrm{~L}^{* * *}$ & $\mathrm{~L}^{* *}$ & NS & $\mathrm{L}^{*}$ \\
\hline 3.5 & 1.3 & 2.8 & 29.3 & 14.5 & 7.3 & 5.6 & 10.2 & 59.4 & 46.4 & 23 \\
\hline 5.9 & 1.0 & 6.8 & 54.5 & 18.0 & 10.3 & 42.8 & 19.2 & 77.2 & 60.9 & 20.4 \\
\hline 8.3 & 60.3 & 19.0 & 137.3 & 52.5 & 34.3 & 88.06 & 20.1 & 77 & 73.7 & 18.1 \\
\hline 10.6 & 65.3 & 19.3 & 150.0 & 59.3 & 37.5 & 161.2 & 25.4 & 68.7 & 81.6 & 18.2 \\
\hline \multirow[t]{2}{*}{ Significance } & $\mathrm{L}^{* * *}$ & $\mathrm{~L}^{* * *}$ & $\mathrm{~L}^{* * *}$ & $\mathrm{~L}^{* * *}$ & $\mathrm{~L}^{* * *}$ & $\mathrm{~L}^{* * *}$ & $\mathrm{~L}^{* *}$ & NS & NS & NS \\
\hline & $\mathrm{Q}^{* *}$ & $\mathrm{Q}^{* * *}$ & $\mathrm{Q}^{* * *}$ & $\mathrm{Q}^{* * *}$ & $\mathrm{Q}^{* * *}$ & $\mathrm{Q}^{* * *}$ & $\mathrm{Q}^{* *}$ & NS & NS & NS \\
\hline
\end{tabular}

${ }^{\mathrm{z}}$ Substrate solution nutrient concentrations obtained by the pourthrough method (Wright, 1986).

${ }^{\mathrm{y}} 1 \mathrm{mg} \cdot \mathrm{L}^{-1}=1 \mathrm{ppm}$.

${ }^{\mathrm{x}}$ Nonsignificant (NS) or significant at $P \leq 0.05(*), 0.01(* *)$, or $0.001(* * *)$.

${ }^{\mathrm{w}} \mathrm{L}=$ linear; $\mathrm{Q}=$ quadratic response for concentration at $*, * *$, or $* * *$.

vPine tree substrate produced from 12-year-old loblolly pine trees harvested at ground level, delimbed, chipped, and hammer milled to pass through a 6.35-mm screen.

Table 3. Leaf tissue analysis taken on 22 Nov. 2005 and 25 May 2007 for japanese holly grown in pine bark or pine tree substrate and fertilized with four rates of Osmocote Plus $15 \mathrm{~N}-3.9 \mathrm{P}-10 \mathrm{~K}$.

\begin{tabular}{|c|c|c|c|c|c|c|}
\hline \multirow{3}{*}{$\begin{array}{l}\text { Treatment } \\
\text { Osmocote }\left(\mathrm{kg} \cdot \mathrm{m}^{-3}\right)\end{array}$} & \multicolumn{3}{|c|}{2005} & \multicolumn{3}{|c|}{2007} \\
\hline & $\overline{\mathrm{N}^{2}}$ & $\mathrm{P}^{\mathrm{z}}$ & $\mathrm{K}^{\mathrm{z}}$ & $\mathrm{N}$ & $\mathrm{P}$ & $\mathrm{K}$ \\
\hline & \multicolumn{3}{|c|}{ 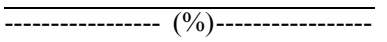 } & \multicolumn{3}{|c|}{ 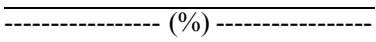 } \\
\hline \multicolumn{7}{|l|}{ Pine bark } \\
\hline 3.5 & 3.19 & 0.23 & 1.77 & 4.04 & 0.25 & 1.51 \\
\hline 5.9 & 3.86 & 0.35 & 2.04 & 4.52 & 0.39 & 1.75 \\
\hline 8.3 & 4.10 & 0.42 & 2.16 & 4.61 & 0.47 & 1.95 \\
\hline 10.6 & 3.93 & 0.45 & 2.22 & 4.39 & 0.36 & 1.64 \\
\hline \multirow{2}{*}{ Significance $^{y x}$} & $\mathrm{~L}^{*}$ & $\mathrm{~L}^{* * *}$ & $\mathrm{~L}^{* * *}$ & $\mathrm{~L}^{* * *}$ & $\mathrm{~L}^{* * *}$ & $\overline{\mathrm{L}^{* * *}}$ \\
\hline & $\mathrm{Q}^{*}$ & $\mathrm{Q}^{* * *}$ & $\mathrm{Q}^{* * *}$ & $\mathrm{Q}^{* * *}$ & $\mathrm{Q}^{* * *}$ & $\mathrm{Q}^{* * *}$ \\
\hline \multicolumn{7}{|l|}{ Pine tree substrate ${ }^{\mathrm{w}}$} \\
\hline 3.5 & 1.19 & 0.17 & 1.36 & 2.51 & 0.13 & 1.61 \\
\hline 5.9 & 2.87 & 0.25 & 1.99 & 3.96 & 0.44 & 1.97 \\
\hline 8.3 & 2.96 & 0.34 & 2.28 & 4.81 & 0.73 & 2.25 \\
\hline 10.6 & 2.68 & 0.31 & 2.10 & 5.01 & 0.75 & 2.83 \\
\hline \multirow{2}{*}{ Significance } & NS & $\mathrm{L}^{* * *}$ & $\mathrm{~L}^{* *}$ & $\mathrm{~L}^{*}$ & $\mathrm{~L}^{*}$ & NS \\
\hline & $\mathrm{Q}^{*}$ & $\mathrm{Q}^{* * *}$ & $\mathrm{Q}^{* * *}$ & $\mathrm{Q}^{* * *}$ & $\mathrm{Q}^{* * *}$ & $\mathrm{Q}^{* * *}$ \\
\hline Substrate & 0.0001 & 0.0001 & 0.0596 & 0.0002 & 0.0020 & 0.0001 \\
\hline Fertilizer rate & 0.0022 & 0.0001 & 0.0001 & 0.0001 & 0.0001 & 0.0001 \\
\hline Substrate $\times$ fertilizer rate & 0.3749 & 0.3213 & 0.0260 & 0.0001 & 0.0001 & 0.0001 \\
\hline
\end{tabular}

${ }^{\mathrm{z}}$ Tissue analysis performed on the most recently matured leaves per plant.

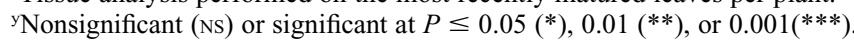

${ }^{\mathrm{x}} \mathrm{L}=$ linear; $\mathrm{Q}=$ quadratic response for concentration at $*, * *$, or $* * *$.

wine tree substrate produced from 12-year-old loblolly pine trees harvested at ground level, delimbed, chipped, and hammer milled to pass through a 6.35 -mm screen.

(Table 2) also in the experiment. The lower $\mathrm{EC}$ and substrate solution nutrient levels in azalea may be the result of different growth rates between azalea and japanese holly with azalea having more shoot growth than japanese holly $(\approx 18 \mathrm{~g}$ for azalea and $11 \mathrm{~g}$ for japanese holly; Fig. 3) suggesting that azalea plants were using more nutrients from the substrate solution for growth (lowering the EC and nutrient levels) and requiring more frequent irrigations than japanese holly, leading to potentially more nutrient leaching. In contrast, the smaller holly plants required less irrigation and therefore conceivably had less nutrient leaching during this experiment causing the higher (and statistically similar) substrate solution EC levels between substrates (Table 1) and generally higher nutrient levels (Table 2) in both PB and PTS in 2007. Tissue $\mathrm{N}$ concentrations in azalea were not within the sufficiency range $(2.0 \%$ to $3.0 \%)$ until the $3.5 \mathrm{~kg} \cdot \mathrm{m}^{-3}$ fertilizer rate for $\mathrm{PB}$ plants $(2.4 \%$ tissue $\mathrm{N})$ and at the $5.9 \mathrm{~kg} \cdot \mathrm{m}^{-3}$ fertilizer rate for PTS-grown plants $(2.3 \%$ tissue N) (Table 5). At these fertilizer rates, maximum shoot growth occurred in each substrate.

Lower substrate solution EC for PTS compared with PB has been reported previously by Wright and Browder (2005) and Wright et al. (2006). The reason for this difference may be twofold. First, PTS is more porous and has a significantly lower CEC compared with PB (Table 4), which could result in more nutrient leaching from PTS. The second may relate to higher rates of microbial $\mathrm{N}$ immobilization demonstrated with PTS. Substrate $\mathrm{CO}_{2}$ efflux for PTS (Figs. 1C and 2C) was higher than in $\mathrm{PB}$ and likely related to the higher carbon: nitrogen ratio of PTS (550:1) compared with PB (50:1) (Bollen and Lu, 1957; Tisdale et al., 1993). Similar to our results (Figs. 1A and $2 \mathrm{C}$ ), previous work has shown a reduction in substrate $\mathrm{CO}_{2}$ efflux as fertilizer rate increased (Maas and Adamson, 1972) possibly as a result of the increased salt concentration, which apparently either modified the microflora in the substrate or reduced their activity (Allison, 1965). This study provides preliminary evidence that $\mathrm{N}$ immobilization could be a viable reason for the higher fertilizer requirement in PTS. Substrate solution $\mathrm{pH}$ was lower for PB than for PTS reflective of inherently higher $\mathrm{pH}$ of PTS, which may be the result of the chemical nature of freshly ground wood. The $\mathrm{pH}$ levels for both substrates in these studies are acceptable for both japanese holly and azalea. There was no visual substrate shrinkage or decomposition in PTS during the 3-month experiment, which is consistent with observations from other unpublished studies by these authors. Future studies to investigate the rate and impact of decomposition of PTS in containers during long-term production will be reported. In addition to evaluating PTS decomposition in containers, different methods of PTS storage and the effect of storage on PTS over time will be investigated.

A higher fertilizer requirement for PTS compared with PB is of concern and must be considered when using PTS as a substrate for woody nursery crops. Fertilizer recommendations for growing woody crops in PTS will 
Table 4. Physical and chemical properties of unamended pine bark and pine tree substrates used in the production of japanese holly in $2005^{z}$.

\begin{tabular}{|c|c|c|c|c|c|}
\hline Substrates & $\begin{array}{c}\text { Total porosity } \\
\text { (\% vol) }\end{array}$ & $\begin{array}{l}\text { Air space }{ }^{\mathrm{x}} \\
\text { (\% vol) }\end{array}$ & $\begin{array}{c}\text { Container } \\
\text { capacity }^{\mathrm{w}} \\
(\% \text { vol })\end{array}$ & $\begin{array}{c}\text { Bulk } \\
\text { density } \\
\left(\mathrm{g} \cdot \mathrm{cm}^{-3}\right)\end{array}$ & $\begin{array}{c}\text { Cation exchange } \\
\text { capacity }^{\mathrm{u}} \\
\left(\mathrm{cmol} \cdot \mathrm{L}^{-1}\right)\end{array}$ \\
\hline Pine bark & $82.9 \mathrm{a}^{\mathrm{t}}$ & $26.9 \mathrm{~b}$ & $56.1 \mathrm{a}$ & $0.20 \mathrm{a}$ & $17.9 \mathrm{a}$ \\
\hline Pine tree & & & & & \\
\hline substrate $^{\mathrm{s}}$ & $83.6 \mathrm{a}$ & $38.2 \mathrm{a}$ & $45.2 \mathrm{~b}$ & $0.15 \mathrm{a}$ & $2.1 \mathrm{~b}$ \\
\hline BMP guidelines $^{\mathrm{r}}$ & $50-85$ & $10-30$ & $45-65$ & $0.19-0.70$ & - \\
\hline
\end{tabular}

${ }^{\mathrm{z}}$ Data were collected from three samples per substrate on 13 Sept. 2005 and represented as means. Analysis performed using the North Carolina State University Porometer method (Fonteno et al., 1995).

y Total porosity is equal to container capacity + air space.

${ }^{\mathrm{x}}$ Air space is the volume of water drained from the sample $\div$ volume of the sample

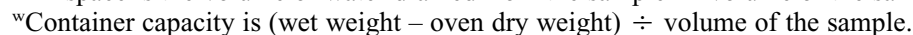

${ }^{v}$ Bulk density after forced-air drying at $105{ }^{\circ} \mathrm{C}$ for $48 \mathrm{~h} ; 1 \mathrm{~g} \cdot \mathrm{cm}^{-3}=0.5780 \mathrm{oz} / \mathrm{inch}^{3}$.

"Cation exchange capacity determined by A\&L Eastern Agricultural Laboratories (Richmond, VA) using the AOAC International Official Method (Thrope, 1973).

${ }^{\mathrm{t}}$ Means were separated within column between pine bark and pine tree substrate by least significance difference at $P \leq 0.05$.

sPine tree substrate produced from 12-year-old loblolly pine trees harvested at ground level, delimbed, chipped, and hammer milled to pass through a $6.35-\mathrm{mm}$ screen.

${ }^{\mathrm{r}} \mathrm{BMP}=$ Best Management Practices recommended sufficiency ranges for physical properties of substrates used in general nursery production (Yeager et al., 2007).

Table 5. Leaf tissue analysis taken on 25 May 2007, average electrical conductivity (EC) levels, and pH values over the experiment and substrate solution nutrients sampled on $20 \mathrm{Apr}$. 2007 for azalea grown in pine bark or pine tree substrate and fertilized with four rates of Osmocote Plus $15 \mathrm{~N}-3.9 \mathrm{P}-10 \mathrm{~K}$.

\begin{tabular}{|c|c|c|c|c|c|c|c|c|}
\hline \multirow{3}{*}{$\begin{array}{l}\text { Treatment } \\
\text { Osmocote }\left(\mathrm{kg} \cdot \mathrm{m}^{-3}\right)\end{array}$} & \multicolumn{3}{|c|}{ Leaf tissue ${ }^{z}$} & \multicolumn{5}{|c|}{ Substrate solution $^{\mathrm{y}}$} \\
\hline & $\overline{\mathrm{N}}$ & $\mathrm{P}$ & $\mathrm{K}$ & $\mathrm{pH}$ & $\mathrm{EC}$ & $\mathrm{NO}_{3}-\mathrm{N}$ & $\mathrm{P}$ & $\mathrm{K}$ \\
\hline & \multicolumn{3}{|c|}{ 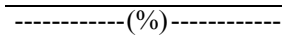 } & & $\left(\mathrm{dS} \cdot \mathrm{m}^{-3}\right)^{\mathrm{x}}$ & \multicolumn{2}{|c|}{----- $\left(\mathrm{mg} \cdot \mathrm{L}^{-1}\right)^{\mathrm{x}}$} & \\
\hline \multicolumn{9}{|l|}{ Pine bark } \\
\hline 1.2 & 1.40 & 0.29 & 0.91 & 4.9 & 0.60 & 4.2 & 2.3 & 18.6 \\
\hline 3.5 & 2.42 & 0.26 & 1.21 & 4.7 & 0.83 & 22.7 & 6.1 & 45.6 \\
\hline 5.9 & 2.86 & 0.24 & 1.57 & 4.4 & 1.5 & 62.5 & 11.2 & 99.5 \\
\hline 8.3 & 3.07 & 0.24 & 1.75 & 4.3 & 2.04 & 96.4 & 24.3 & 122.5 \\
\hline \multirow[t]{2}{*}{ Significance $^{\mathrm{wV}}$} & $\mathrm{L}^{* * *}$ & NS & $\mathrm{L}^{* * *}$ & $\mathrm{~L}^{* * *}$ & $\mathrm{~L}^{* * *}$ & $\mathrm{~L}^{* * *}$ & $\mathrm{~L}^{* *}$ & $\mathrm{~L}^{* * *}$ \\
\hline & $\mathrm{Q}^{* * *}$ & $\mathrm{Q}^{* * *}$ & $\mathrm{Q}^{* * *}$ & $\mathrm{Q}^{* * *}$ & $\mathrm{Q}^{* * *}$ & $\mathrm{Q}^{* * *}$ & $\mathrm{Q}^{* *}$ & $\mathrm{Q}^{* * *}$ \\
\hline \multicolumn{9}{|l|}{$\overline{\text { Pine tree substrate }}{ }^{\mathrm{u}}$} \\
\hline 1.2 & 0.95 & 0.21 & 0.63 & 5.5 & 0.41 & 3.2 & 1.0 & 18.7 \\
\hline 3.5 & 1.52 & 0.54 & 1.49 & 5.5 & 0.60 & 10.4 & 4.7 & 24.5 \\
\hline 5.9 & 2.33 & 0.55 & 1.89 & 5.6 & 0.71 & 43.5 & 17.2 & 44.8 \\
\hline 8.3 & 2.95 & 0.37 & 2.07 & 5.4 & 1.6 & 75.6 & 20.7 & 57.2 \\
\hline \multirow[t]{2}{*}{ Significance } & $\mathrm{L}^{* * *}$ & $\mathrm{~L}^{* *}$ & L*** & NS & $\mathrm{L}^{* * *}$ & $\mathrm{~L}^{* * *}$ & $\mathrm{~L}^{* *}$ & $\mathrm{~L}^{* * *}$ \\
\hline & $\mathrm{Q}^{* * *}$ & $\mathrm{Q}^{* *}$ & $\mathrm{Q}^{* * *}$ & $\mathrm{Q}^{* * *}$ & $\mathrm{Q}^{* * *}$ & $\mathrm{Q}^{* * *}$ & $\mathrm{Q}^{* *}$ & $\mathrm{Q}^{* * *}$ \\
\hline Substrate & 0.0001 & 0.0001 & 0.0009 & 0.0001 & 0.0001 & 0.4762 & 0.0980 & 0.0001 \\
\hline Fertilizer rate & 0.0001 & 0.0001 & 0.0001 & 0.0001 & 0.0001 & 0.0001 & 0.0001 & 0.0001 \\
\hline Substrate $\times$ fertilizer rate & 0.0001 & 0.0001 & 0.0001 & 0.0001 & 0.0029 & 0.0004 & 0.0885 & 0.0015 \\
\hline
\end{tabular}

${ }^{\mathrm{z}}$ Tissue analysis performed on the most recently matured leaves per plant.

${ }^{\mathrm{y}} \mathrm{pH}, \mathrm{EC}$, and substrate solution nutrient concentrations were obtained by the pourthrough method.

${ }^{\mathrm{x}} 1 \mathrm{dS} \cdot \mathrm{m}^{-3}=1 \mathrm{mmho} / \mathrm{cm}, 1 \mathrm{mg} \cdot \mathrm{L}^{-1}=1 \mathrm{ppm}$.

${ }^{w}$ Nonsignificant (NS) or significant at $P \leq 0.05(*), 0.01(* *)$, or $0.001(* * *)$.

${ }^{\mathrm{v}} \mathrm{L}=$ linear; $\mathrm{Q}=$ quadratic response for concentration at $*, * *$, or $* * *$.

uPine tree substrate produced from 12-year-old loblolly pine trees harvested at ground level, delimbed, chipped, and hammer milled to pass through a $6.35-\mathrm{mm}$ screen.

help growers maximize plant growth and minimize fertilizer use, which can reduce both fertilizer costs and the potential for excess nutrient losses in to the nursery runoff system. Further work is needed to determine the extent of nutrient leaching in PTS as well as establish irrigation requirements during crop production with PTS. The addition of various proportions of $\mathrm{PB}$, as well as other organic materials and composts, to PTS may increase the CEC and reduce nutrient leaching as well as improving (decreasing) the carbon:nitrogen ratio of PTS (currently at $550: 1)$ potentially reducing $\mathrm{N}$ immobilization and reducing the need for additional fertilizer for PTS. Manufacturing PTS to have more small particles (fines) could result in higher container capacity and less porosity to reduce irrigation (and nutrient) leaching. The reason for lower substrate solution nutrient levels in PTS needs further investigation to more fully understand and manage fertility requirements when growing plants in PTS during short- and long-term production. Future studies plan to investigate the influence of a relatively high microbial activity in PTS (evident by increased substrate $\mathrm{CO}_{2}$ levels) on substrate nutrient levels, the rate and significance of nitrogen immobilization, and on substrate decay over longer plant production cycles and in larger containers.

\section{Literature Cited}

Allison, F.E. 1965. Decomposition of wood and bark sawdusts in soil, nitrogen requirements, and effects on plants. U.S. Dept. Agr. Tech. Bull. No. 1332.

Bilderback, T.E. 2001. Environmentally compatible container plant production practices. Acta Hort. 548:311-318.

Bollen, W.B. and K.C. Lu. 1957. Effect of Douglas-fir sawdust mulches and incorporations on soil microbial activities and plant growth. Soil Sci. Soc. Proc. 21:35-41.

Boyer, C.R., G.B. Fain, C.H. Gilliam, T.V Gallagher, H.A. Torbert, and J.L. Sibley. 2006. Clean chip residual: A new substrate component for container-grown plants. Proc. Southern Nursery Assn. Res. Conf. 47:274-277.

Brooker, J.R., R.A. Hinson, and S.C. Turner. 2000. Trade flows and marketing practices within the united states nursery industry: 1998. Southern Coop. Series Bulletin 397.

Carlile, W.R. 2004. Growing media and the environmental lobby in the UK 1997-2001. Acta Hort. 644:107-113.

Conover, C.A. and R.T. Poole. 1983. Utilization of Melaleuca quinquenervia as a potting medium component for greenhouse production of foliage plants. HortScience 18:886-888.

Fain, G.B., C.H. Gilliam, J.L. Sibley, and C.R. Boyer. 2008. Wholetree substrates derived from three species of pine in production of annual vinca. HortTechnology 18:13-17.

Fonteno, W.C., C.T. Hardin, and J.P. Brewster. 1995. Procedures for determining physical properties of horticultural substrates using the NCSU Porometer. Horticultural Substrates Laboratory, North Carolina State University.

Gouin, F.R. and C.B. Link. 1973. Growth response of container-grown woody ornamentals to slow-release fertilizers. HortScience 8:208209.

Griffith, L. 2007. Potting media's new battles. GrowerTalks 71:58-60.

Gruda, N. and W.H. Schnitzler. 1999. Influence of wood fiber substrates and nitrogen application rates on the growth of tomato transplants. Adv. Hort. Sci. 13:20-24.

Gumy, N. 2001. Toresa and other woodfiber products: Advantages and drawbacks when used in growing media, p. 39-46. Proc. Intl. Peat Symp., Peat in horticulture: Peat and its alternatives in growing media.

Ingram, D.I. and C.R. Johnson. 1983. Melaleuca: An alternative container media component for woody ornamentals. Proc. Fla. State Hort. Soc. 96:254-256.

Kenna, S.W. and C.E. Whitcomb. 1985. Hardwood chips as an alternative medium for container plant production. HortScience 20:867-869.

Laiche A.J., Jr. and V.E. Nash. 1986. Evaluation of pine bark, pine bark with wood, and pine tree chips as components of a container plant growing media. J. Environ. Hort. 4:22-25.

Lu, W., J.L. Sibley, C.H. Gilliam, J.S. Bannon, and Y. Zhang. 2006. Estimation of U.S. bark generation and implications for horticultural industries. J. Environ. Hort. 24:29-34.

Maas, E.F. and R.M. Adamson. 1972. Resistance of sawdusts, peats, and bark to decomposition in the presence of soil and nutrient solution. Soil Sci. Soc. Amer. Proc. 36:769-772.

Mills, H.A. and J.B. Jones, Jr. 1996. Plant analysis handbook 1l. Micromacro Publishing, Athens, GA.

Niemiera, A.X. and C.E. Leda. 1993. Nitrogen leaching from Osmocote-fertilized pine bark at leaching fractions of 0 to 0.4 . J. Environ. Hort. 11:75-77.

Penningsfeld, F. 1992. Toresa, a new substrate for soilless culture. Proc. Intl. Congress on Soilless Culture. p. 335-345. 
Riviere, L.M. and J. Caron. 2001. Research on substrates: State of the art and need for the coming 10 years. Acta Hort. 548:29-41.

Saunders, T.N., R.D. Wright, and J.F. Browder. 2005. Chipped pine logs: A potential substrate for nursery and greenhouse crops. Proc. Southern Nursery Assn. Res. Conf. 50:112114.

Thrope, V.A. 1973. Collaborative study of the cation exchange capacity of peat materials. J. AOAC 56:154-156.

Tisdale, S.L., W.L. Nelson, J.D. Beaton, and J.L. Havlin. 1993. Soil fertility and fertilizers. Macmillan Publishing, New York, NY.
Wang, W.J., R.C. Dalal, P.W. Moody, and C.J. Smith. 2003. Relationships of soil respiration to microbial biomass, substrate availability and clay content. Soil Biol. Biochem. 35:273-284.

Warren, S.L. and T.E. Bilderback. 2004. Irrigation timing: Effect on plant growth, photosynthesis, water-use efficiency and substrate temperature. Acta Hort. 644:29-37.

Wright, R.D. 1986. The pour-through nutrient extraction procedure. HortScience 21:227229.

Wright, R.D. and J.F. Browder. 2005. Chipped pine logs: A potential substrate for greenhouse and nursery crops. HortScience 40:1513-1515.
Wright, R.D., J.F. Browder, and B.E. Jackson. 2006. Ground pine chips as a substrate for container-grown woody nursery crops. J. Environ. Hort. 24:181-184.

Wright, R.D., B.E. Jackson, J.F. Browder, and J.G. Latimer. 2008. Growth of chrysanthemum in ground pine trees requires additional fertilizer. HortTechnology 18:111-115.

Yeager, T.H., D.C. Fare, J. Lea-Cox, J. Ruter, T.E. Bilderback, C.H. Gilliam, A.X. Niemiera, S.L. Warren, T.E. Whitwell, R.D. Wright, and K.M. Tilt. 2007. 2nd Ed. Best management practices: Guide for producing container-grown plants. Southern Nurserymen's Assoc., Marietta, GA. 